\title{
Underlying Mechanism of Coffee as Inhibitor Adipogenesis for Complementary Medicine Use in Obesity
}

\section{Lelyana $\mathbf{R}^{*}$}

Medicine Faculty of Diponegoro University, Semarang, Central Java, Indonesia

\begin{abstract}
Introduction: Obesity is a problem that affects the world community for early mortality. Coffee is the favorite drink that contains caffeine and the main form has been consumed since the days of our ancestors. Caffeine was considered to have a negative effect on health, but the most current studies prove that caffeine is beneficial to health, as well as in the treatment of obesity, but not much is understood about the mechanism of action of caffeine for obesity. The purpose of this paper to discuss the mechanism of weight loss in the form of coffee contains caffeine.
\end{abstract}

Methode: Systematic review.

Result: Caffeine of coffee has properties as an inhibitor of adipogenesis.

Discussion: Caffeine has thermogenesis effect which can reduce the size and number of adipose cells so that the accumulation of adipose tissue will be reduced. Finally, the weight will come down and achieved improvement of organ function and adipose tissue.

Conclusion: Caffeine coffee potentially loses weight obese due to their properties as an inhibitor of adipogenesis of caffeine of coffee.

Keywords: Coffee; Caffeine; Inhibitor adipogenesis; Obesity

\section{Introduction}

Complementary medicine is a term for non-conventional medicine in several countries. WHO uses traditional medicine strategy in 20142023 to support the improvement of public health services world [1]. Obesity and overweight is one of the chronic diseases that would have increased mortality [2], especially in the country - a country whose population is obese and many overweight. Mortality in obesity is due to the onset of cardiovascular disease and insulin resistance so that the person is suffering from diabetes mellitus. Area subcutan, retroperitoneal and visceral is an area in which the distribution of adipose tissue more distributed. The third area of distribution of the adipose tissue is characteristic of the distribution of adipose tissue of obese abdominal. Risiko atherogenic that cause insulin resistance associated with abdominal obesity. Atherogenic risk, diabetogenic and hypertensiogenic associated with visceral fat distribution in the area because of the accumulation of visceral adipose tissue area further facilitates an increase in free fatty acids to the liver via the portal vein [3].

Obesity is an excessive accumulation of adipose tissue in the body so the secretion of pro-inflammatory responses increased in chronic period [4,5]. Adipose tissue is the tissue that reflects the body's immune system and is one of the endocrine organs. Excessive immune response due to increased secretion of chronic inflammatory response will cause damage to organs and tissues of individuals with obesity leading to diabetes mellitus [6,7].

Complementary medicine is given to prevention and management of some chronic diseases. Products used include complementary medicine made from herbs that contain parts of plants or plant active ingredients, but some countries do not always use materials containing parts of plants [1]. Management of chronic diseases such as obesity and diabetes mellitus begins with attention to diet so that the management did not experience weight gain that resulted in the number and size of adipose cells which continue to multiply.
Public health care efforts in the weight loss program that focuses on obesity or overweight people to eat healthy and increase the activity of exercise, had failed during the past 30 years. This triggered a new development to prioritize programs increased physical activity to manage weight [8]. Obesity and overweight patients who experienced weight loss of $5-10 \%$ of the total weight will benefit the health and improve the risk of cardiovascular disease marked by improvements in blood pressure, blood cholesterol levels and blood sugar [4,9]. The use of herbs has increased due to the cost and side effects that are used for herbal treatment is lower than the cost and side effects incurred for the treatment of non-herbal $[1,10]$. The results of a recent study state that in addition to herbs, consumption of vegetables and fruits will reduce the risk of chronic disease because it contains antioxidants like polifenol. Antioksidan will reduce oxidative stress. In fact, coffee included beverages containing high levels of antioxidants [11,12]. Strategy complementer medicine should be improved in the management of various diseases because of this strategy is prioritizing the management of food consumption in order to prevent an increase in oxidative stress $[13,14]$.

Coffee is one beverage that mainly contains caffeine and proved unable to lose weight due to the effects of caffeine work, one of them as a stimulant. An epidemiological study proves that coffee consumption reduces weight gain in obese men [15]. Kafein is a major stimulant of

*Corresponding author: Rosa Lelyana, Medicine Faculty of Diponegoro University, Semarang, Central Java, Indonesia, Tel: 0815764-5736; E-mail: rl3lyana@gmail.com

Received February 09, 2017; Accepted February 20, 2017; Published February 24, 2017

Citation: Lelyana R (2017) Underlying Mechanism of Coffee as Inhibitor Adipogenesis for Complementary Medicine Use in Obesity. J Nanomed Nanotechnol 8: 425. doi: 10.4172/2157-7439.1000425

Copyright: (c) 2017 Lelyana R. This is an open-access article distributed under the terms of the Creative Commons Attribution License, which permits unrestricted use, distribution, and reproduction in any medium, provided the original author and source are credited. 
Citation: Lelyana R (2017) Underlying Mechanism of Coffee as Inhibitor Adipogenesis for Complementary Medicine Use in Obesity. J Nanomed Nanotechnol 8: 425. doi: 10.4172/2157-7439.1000425

Page 2 of 3

coffee and related to weight loss and reduced risk of metabolic syndrome [16]. Consumption of coffee helps the lipid metabolism by increasing thermogenesis as part of an increase in fat oxidation. Caffeine shows antiobesity effect by reducing the size of adipose tissue and cell number of adipocytes, increased heat production from adipose tissue and basal metabolic rate of the body. Caffeine could inhibit cell proliferation and differentiation of adipocytes through inhibition adipogenik related factors [17]. The results of long-term studies have shown that caffeine reduces adipose pad size and the number of cells of adipocytes (Table 1) $[18,19]$ [20]:

Consumption of caffeine will stimulate thermogenesis in 2 ways

- Inhibiting the enzyme phosphodiesterase. Barriers against the action of the enzyme phosphodiesterase will lead to cyclic adenosine monophosphate (cAMP) is not capable of performing hydrolysis to AMP that increased cAMP levels. Increased levels of cAMP will lead to increased activity of the central nervous system so hormone sensitive lipase inactive to active, ultimately encourage lipolysis.

- Through stimulation cycles substrate is Cori cycle and FFA triglyceride cycle [20]. Their Cori cycle may be the answer to why the people who consume coffee will feel the increase in body fitness. Lactate in the muscles will be moved to the liver. Lactate in the liver then be converted into pyruvate, then pyruvate is converted into glucose by the enzyme lactate dehydrogenase, and glucose eventually sent back to the muscle blood circulation. Besides an increase in free fatty acid and lipid oxidation. Caffeine is an antagonist which inhibits the action of adenosine against lipolysis by adenyl cyclase [21]. Caffeine increases energy expenditure by $4-5 \%$ and $10-16 \%$ of fat oxidation through activation of the sympathetic nervous system that is involved in regulation of lipolysis in white adipose tissue and affect the total fat thus affecting the body's metabolic effects such as satiety, thermogenesis and fat oxidation (Figure 1) [20].

\begin{tabular}{|c|c|c|c|c|c|}
\hline Authors & Designs & Samples & Outcome & Measurements & Results \\
\hline $\begin{array}{l}\text { Acheson et al. } \\
\text { [21] }\end{array}$ & Experimental study & $\begin{array}{l}8 \text { healthy male volunteers, } \\
\text { approved by the ethical } \\
\text { committee of the Faculty } \\
\text { of Medicine, Lausanne } \\
\text { University. }\end{array}$ & $\begin{array}{l}\text { Biological mechanisms of } \\
\text { lipolytic effect of caffeine } \\
\text { and the influence of } \\
\text { caffeine are mediated } \\
\text { via Sympathetic nervous } \\
\text { system }\end{array}$ & $\begin{array}{c}\text { Plasma and urine samples, } \\
\text { breath samples, stable isotope } \\
\text { analysis }\end{array}$ & $\begin{array}{l}\text { Sympathetic nervous system is } \\
\text { mediator for activiting caffeine. }\end{array}$ \\
\hline $\begin{array}{l}\text { Hiroshi et al. } \\
\text { [22] }\end{array}$ & Experimental study & $\begin{array}{c}\text { Male ddy mice were fed a } \\
\text { standard diet containing } \\
\text { green coffee bean extract } \\
\text { and its components (caffeine } \\
\text { and chlorogenic acid) for } \\
14 \text { days }\end{array}$ & $\begin{array}{l}\text { Effect of green coffee } \\
\text { bean extract on fat } \\
\text { accumulation in mice }\end{array}$ & $\begin{array}{c}\text {-Measurements of mice body } \\
\text { weight and visceral fats, hepatic } \\
\text { TG, serum TG, hepatic carnitine } \\
\text { palmitoyl transferase }\end{array}$ & $\begin{array}{c}\text { Green coffee bean extra } \\
\text { suppress body weight gain and } \\
\text { visceral fat accumulation in mice. } \\
\text { (Caffeine suppress fat absorption, } \\
\text { chlorogenic acid enhances fat } \\
\text { metabolism in the liver) }\end{array}$ \\
\hline $\begin{array}{l}\text { Shu Hui Su et } \\
\text { al. [23] }\end{array}$ & Experimental study & $\begin{array}{c}\text { Primary rat adipose derived } \\
\text { stem cells (ADSCs) and a } \\
\text { mouse bone marrow stromal } \\
\text { cell line in vitro }\end{array}$ & $\begin{array}{l}\text { Effect of caffeine on } \\
\text { adipogenesis }\end{array}$ & $\begin{array}{l}\text { Oil red O, Nila Red Staining } \\
\text { and FACScan flow cytometry }\end{array}$ & $\begin{array}{l}\text { Caffeine was able to inhibit } \\
\text { adipogenic differentiation of } \\
\text { ADSCs and M2-10B4 cells }\end{array}$ \\
\hline $\begin{array}{l}\text { Su Jin Song et } \\
\text { al. [24] }\end{array}$ & Experimental study & 48 male $\mathrm{C} 57 \mathrm{BL} / 6 \mathrm{~N}$ mice & $\begin{array}{l}\text { Mechanisms of weight } \\
\text { loss product from green } \\
\text { coffee bean extract }\end{array}$ & $\begin{array}{c}\text { HPLC analysis of green coffee } \\
\text { bean extract, histological and } \\
\text { biochemical anslysis, oral } \\
\text { glucose tolerance test, RT- } \\
\text { PCR, Western Blood Analysis }\end{array}$ & $\begin{array}{l}\text { Green coffee bean extract reduces } \\
\text { visceral fat -pad accumulation }\end{array}$ \\
\hline $\begin{array}{l}\text { Hujuan et al. } \\
\text { [25] }\end{array}$ & EExperimental study & $\begin{array}{c}\text { Eight week old male } \\
\text { C57BL6 mice were fed for } \\
9 \text { weeks ad lib on normal } \\
\text { diet, high fat diet, high fat } \\
\text { diet of coffee containing } \\
2 \% \text { caffeine, decaffeine, } \\
\text { unroasted caffeinated green } \\
\text { coffee }\end{array}$ & $\begin{array}{l}\text { Molecular mechanisms in } \\
\text { the ameliorative effects of } \\
\text { coffee on skeletal muscle } \\
\text { gene expression profiles } \\
\text { in obese animal model }\end{array}$ & $\begin{array}{l}\text { Extract Total RNA and protein } \\
\text { from skeletal muscle were } \\
\text { subjected to microarray } \\
\text { (Mouse genom } 2.0, \text { Affymetric) } \\
\text { and western blotting analyses }\end{array}$ & $\begin{array}{c}\text { Positive effect of coffee } \\
\text { consumption on the prevention of } \\
\text { obesity }\end{array}$ \\
\hline
\end{tabular}

Table 1: The mechanism of coffee as complementary medicine in obesity.

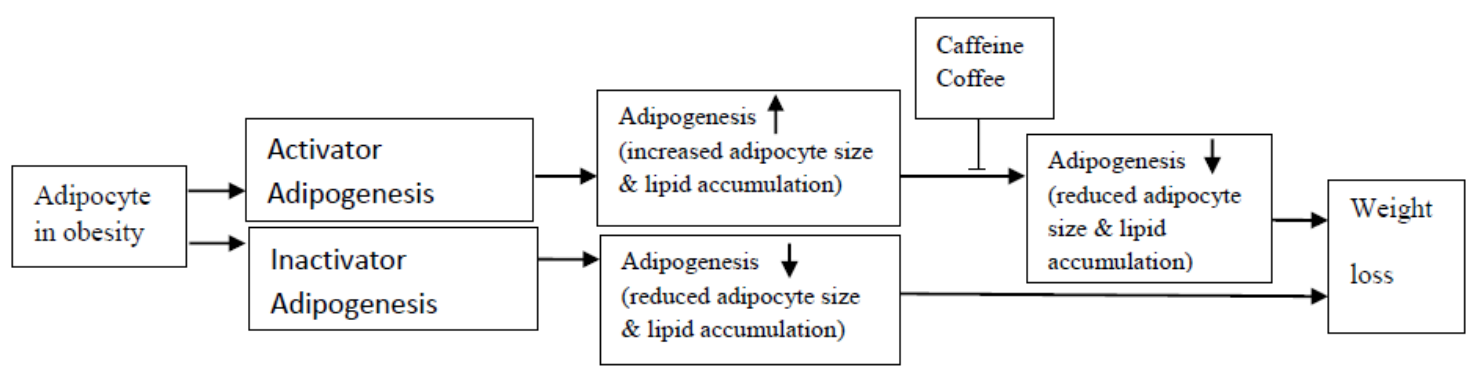

Figure 1: Mechanism of coffee as inhibitor adipogenesis use in obesity. 
Citation: Lelyana R (2017) Underlying Mechanism of Coffee as Inhibitor Adipogenesis for Complementary Medicine Use in Obesity. J Nanomed Nanotechnol 8: 425. doi: 10.4172/2157-7439.1000425

Page 3 of 3

\section{Conclusion}

The caffeine content is an inhibitor of adipogenesis so as to inhibit the adipogenesis adipose cells that cause smaller size and weight reduction. The benefits of coffee consumption on weight is increasing satiety and increase metabolism which helps maintain body weight and weight loss in people who are less physical activity.

\section{References}

1. Paracelso E (2013) Tradotto e pubblicato in italiano a cura dell'Istituto Paracelso. World Health Organization 2014-2023.

2. Flegal KM, Kit BK, Orpana H, Graubard BI (2013) Association of All-Cause Mortality With Overweight and Obesity Using Standard Body Mass Index Categories A Systematic Review and Meta-analysis. JAMA 309: 71-82.

3. Prasad DS, Kabir Z, Dash AK, Das BC (2011)Abdominal obesity, an independent cardiovascular risk factor in Indian subcontinent: A clinico epidemiological evidence summary. J Cadiovasc Dis Res 2: 199-205.

4. Despres JP (2012) Body Fat distribution and risk of cardiovascular disease: Circulation 126: 1301-1313.

5. Hotamisligil GS (2006) Inflammation and metabolic disorders. Nature 444: 860867.

6. Nishimoto S, Fukuda D, Higashikuni Y, Tanaka K, Yoichiro H, et al. (2016) Obesity induced DNA released from adipocytes stimulates chronic adipose tissue inflammation and insulin resistance. Science Advances 2: e1501332.

7. Chakraborty S, Zawieja S, Wang W, Zawieja DC, Muthuchamy M (2010) Lymphatic system: A vital link between metabolic syndrome and inflammation. Ann N Y Acad Sci S1: E94-E102.

8. Wiklund $P(2016)$ The role of physical activity and exercise in obesity and weight management: Time for critical appraisal. Journal of Sport and Health Science 5: 151-154.

9. Wing RR, Lang W, Wadden TA, Safford M, Knowler WC, et al. (2011) Benefits of Modest Weight Loss in Improving Cardiovascular Risk Factors: in Overweight and Obese Individuals With Type 2 Diabetes. Diabetes Care 34: 1481-1486.

10. Market Research News (2011) Global market for weight loss worth US $\$ 586.3$ billion by 2014

11. Carter P, Gray LJ, Troughton J, Khunti K, Davies MJ (2010) Fruit and vegetable intake and incidence of type 2 diabetes mellitus: systematic review and metaanalysis. BMJ 341:c4229.

12. Carlsen MH, Halvorsen BL, Holte K, Bohn SK, Dragland S, et al. (2010) The total antioxidant content of more than 3100 foods, beverages, spices, herbs and supplement used worldwide. Nutrition Journal 9: 3

13. Tapiero H, Tew KD, Ba GN, Mathé G (2002) Polyphenols: do they play a role in the prevention of human pathologies? Biomed Pharmacother 56: 200-207.

14. Greco CM, Nakajima C, Manzi S (2013) Updated Review of Complementary and Alternative Medicine Treatments for Systemic Lupus Erythematosus. Curr Rheumatol Rep 15: 378.

15. Lopez-Garcia E, van Dam RM, Rajpathak S, Willett WC, Manson JE, et al (2006) Changes in caffeine intake and long-term weight change in men and women. Am J Clin Nutr 83: 674-680.

16. Heckman MA, Weil J, Gonzalez de Mejia E (2010) Caffeine (1,3,7-trimethylxanthine) in foods: a comprehensive review on consumption, functionality, safety and regulatory matters. J Food Sci 75: R77-R87.

17. Zheng G, Sayam K, Okubo T, Juneja LR, Oguni I (2004) Anti-obesity effects of three major components of green tea, catechins, caffeine and theanine, in mice. In Vivo 18: 55-62.

18. Muroyama K, Murosaki S, Yamamoto Y, Odaka H, Chung HC, et al. (2003) Anti-obesity effects of a mixture of thiamin, arginine, caffeine, and citric acid in non-insulin dependent diabetic KK mice. Nutr Sci Vitaminol 49: 56-63.

19. Su SH, Shyu HW, Yeh YT, Chen KM, Yeh H, et al. (2013) Caffeine inhibits adipogenic of primary adipose derived stem cells and bone marrow stromal cells. Toxicol in Vitro 27: 1830-1837.

20. Hursel R, Plantenga MSW (2010) Thermogenic ingredients and body weight regulation. International Journal of Obesity 34: 659-669.

21. Acheson KJ, Gremaud G, Meirim I, Montigon F, Krebs Y, et al. (2004) Metabolic effects of caffeine in humans:lipid oxydation or futile cycling? Am J Clin Nutr 79: $40-46$

22. Shimoda H, Seki E, Aitani M (2006) Inhibitory effect of green coffee bean extract on fat accumulation and body weight gain in mice. BMC Complementary and Alternative Medicine 6: 9 .

23. Su Hui, Huey Wen S, Yao Tsung Y, Kuan Ming C, Hua Y, et al. (2013) Caffeine inhibits adipogenic differentiation of primary adipose derived stem cells and bone marrow stromal cells. Journal Toxicol in Vitro 5: 1.

24. Song SJ, Choi S, Park T (2014) Decaffeinated green coffee bean extract attenuates diet induced obesity and insulin resistance in mice. Evidence Based Complementary and Alternative Medicine 1-14.

25. Jia H, Aw W, Egashira K, Takahashi S, Aoyama S, et al. (2012) Coffee intake mitigated inflammation and obesity induced insulin resistance in skeleta muscle of high fat diet induced obese mice. Journal of Nutritional Science and Vitaminology 58: 408-414. 